\title{
The Martyr Queen
}

Constructions of Identity in Mary Stuart's Last Letters

La reine martyre: constructions identitaires dans les dernières lettres de Marie Stuart

\section{Colette H. Winn}

Translator. Nicholas Van Handel and Colette H. Winn

\section{(2) OpenEdition}

\section{Journals}

Electronic version

URL: http://journals.openedition.org/aes/714

DOI: 10.4000/aes.714

ISSN: 2258-093X

\section{Publisher}

Laboratoire LISAA

Electronic reference

Colette H. Winn, «The Martyr Queen », Arts et Savoirs [Online], 6 | 2016, Online since 06 July 2016, connection on 20 April 2019. URL : http://journals.openedition.org/aes/714; DOI : 10.4000/aes.714

This text was automatically generated on 20 April 2019.

Centre de recherche LISAA (Littératures SAvoirs et Arts) 


\title{
The Martyr Queen
}

\author{
Constructions of Identity in Mary Stuart's Last Letters \\ La reine martyre: constructions identitaires dans les dernières lettres de Marie \\ Stuart
}

Colette H. Winn

Translation : Nicholas Van Handel and Colette H. Winn

1 On October $25^{\text {th }}, 1586$, Mary Stuart was found guilty of lèse-majesté by the Privy Council of Queen Elizabeth of England. On February ${ }^{\text {th }}, 1587$, she was decapitated in the great hall of Fotheringhay castle. This is where she spent the last months of her life, forced into total solitude and treated more like a criminal than a queen. Her servants were kept away from her and practically all of the privileges due to her rank were taken away from her. Her guards were unwilling to deliver the letters Mary wrote to Elizabeth.

2 Nevertheless, between the announcement of her death sentence on November $19^{\text {th }}, 1586$, and her execution on February 8th, 1587, Mary Stuart wrote ten letters, most likely unbeknownst to her guards. Apart from the three letters intended for Elizabeth, she addressed three to men of the Church (Pope Sixtus V, the bishop of Glasgow and her chaplain Camille du Préau, whom she was not authorized to see in her last moments), one to her uncle, the Duke of Guise, who was one of the major leaders of the Catholic party in France, one to the Spanish ambassador don Bernard de Mendoza (the king of Spain, Philip II, was one of Mary's political allies) and a last letter with instructions serving as will and testament to the king of France, Henry III, who was also her brother-in-law. Why, on the eve of her execution on the scaffold, did Mary Stuart feel the need to write to these powerful and influential people? Did she still hope that her writings would affect the course of events? Was she looking to prevent her death? Based on the content of her letters, this seems unlikely. In fact, she found comfort in the thought that God had allowed her to die blissfully for her faith and she looked forward to her impending execution. What, then, could have motivated Mary Stuart to devote the last hours of her life to writing letters?

3 Judging from Mary Stuart's last letters, life in prison was not easy for her. These letters reveal a great deal about the hostile prison atmosphere and Mary's lack of power once 
her royal privileges disappeared. In some letters, Mary keeps quiet about the poor treatment inflicted upon her - her silence is indicative of the control exercised by her prison guards - but invites her correspondent to seek information from the message bearer1: “Ce porteur m'a promis de vous conter comme j'ai été traitée rigoureusement par ceux-ci, et mal servie d'autres" 2 (458). At one point, she blames her guards for their extreme severity in response to the slightest request, whether she asks them to leave her a small sum of money to have an annual mass said for the salvation of her soul, to permit her to prepare her will, or to allow her chaplain to accompany her to her final resting place. Elsewhere, she gives concrete details about the harassment to which she is subjected, "l'on m'a tout osté icy... ils m'[ont] quasi rendu impotente"3 (439). The removal of the insignia of her royalty, even though she was still queen, seems to have been particularly insulting to her, "ils vinrent avant-hier lundi ôter mon dais, disant que je n'étais plus qu'une femme morte sans nulle dignité" 4 (459). But most humiliating were the degrading images and tales circulated by her guards. These images show the tragic consequences that the accusation of lèse-majesté had for her both as a woman and as the Queen of Scotland. The association between death and the loss of dignity ("une femme morte sans nulle dignité", "une femme morte sans aucun honneur ny dignité de royne" p. 459, 469) refers not only to the ignominious death to which Mary Stuart was sentenced, but also to her ruined reputation. In her work on criminal punishments in early modern France, Nicole Gonthier notes that a person who has lost his or her reputation has lost credibility in society and therefore the trust of others ${ }^{6}$. Did Mary Stuart, then, turn to writing in order to save her reputation from the degradation of prison? Did she take up her pen to rectify the disparaging image of her spread by her guards? Did she see letterwriting as her last chance to recover her credibility and defy her condemnation to silence and oblivion?

Each letter is addressed to a unique, named recipient. However, the content of the letters, the tone, and the absence of intimacy lead us to believe that Mary Stuart is actually writing for posterity. Everything in these letters relates to politico-religious issues, which seems to indicate that letter-writing is an instrument in service to a cause, a means by which Mary Stuart can confront the enemies of her faith. The solemnity of her statements suggests that these letters were meant as much for the readers of tomorrow as for the recipient whose name is mentioned and that they have been conceived as a "Mémorial', un reliquaire de soi que d'autres pourront exhumer ultérieurement." ${ }^{\prime 8}$ None of the letters contains private information. Thus, they could be circulated without inconvenience for the correspondents. For example, Mary Stuart informs Mendoza of a letter she wrote to the King of Spain concerning her decision to cede to him her rights to the throne of England; then she declares, “j'en écris autant à sa Sainteté" (p. 459). Elsewhere, she asks her correspondent to let others know what she writes: she invites the duke of Guise to share with the ambassador of Spain the information she divulges in her letter to him and the Pope to share with the kings the information she discloses (p. 451). Finally, the fact that she avoids naming certain people whom she and her correspondent know shows that she suspects that others will read her letters.

Let's consider for a moment the unique aspects of the letters: 1) the female subject constructs herself in full awareness that she is being seen by her correspondent ${ }^{10}$. This reflexive relationship, present in all correspondence, could be described as "seeing oneself seen"1. The "mise en scene" already present in epistolary exchange is accentuated here as in any "Lettres ostensibles" ${ }^{12}$. In her letters, Mary Stuart provides her 
correspondent with insight into her person and character, hoping "the image her correspondent holds of her coincides with the image she has of herself." ${ }^{13}$ In other words, she expects her correspondent to be a "complicit partner" who will legitimize the representations she gives of herself. 2) The letters conserve traces of the ephemeral (in other words, of who she once was). This material trace is tangible proof of her identity ${ }^{14}$ that could be produced publically if needed. 3) Finally, writing a letter is to take action and influence the course of events ${ }^{15}$. Letters have the power to alter reality, to transform a situation, or to bring about an event. Some doubt still remains today concerning the survival of Mary Stuart's final letters and their reception. According to Prince Labanoff ${ }^{16}$, on the $25^{\text {th }}$ of November, 1586, Mary Stuart was authorized to see her chaplain Camille du Préau and it was at this moment that she secretly handed him the letters she had written since her death sentence. These letters remained in the hands of Préau and Mary Stuart's servants until they were allowed to return to France. Her letters were not delivered to the people to whom they were addressed until September or October of 1587. At that time the image of the "martyr queen" had begun to circulate throughout Europe due to the abundant partisan literature that appeared right after her execution ${ }^{17}$. This image coincides with the one Mary Stuart tried to impress upon her correspondents in her last letters.

In spite of the hopeless position in which Mary Stuart found herself in Fotheringhay's prison, where she no longer expected anything more from the world of the living, she still had the freedom to carry out a final wish: to make sure that her relatives, friends and allies -and, beyond them, future generations- conserved her "true" image. The fact that she had nothing to lose (her sentence was irrevocable) vouches for her sincerity. These letters provided her with the means to accomplish this last wish (posthumous rehabilitation). In contrast to the degrading portrayal of her conveyed by her guards that of a woman dead and disgraced since she had lost her title of queen and of a criminal -, the letters attempt to reconstruct three alternative images: ${ }^{18}$ the image of the queen, that of an innocent victim and that of a martyred witness. Let's examine now the rhetorical strategies that Mary Stuart used to achieve this goal.

7 Repetition and demonstrative reasoning are used to construct the image of the queen in contrast to the image of the dead and disgraced woman depicted by her guards. The word queen is used no less than ten times in the letters as if Mary Stuart wanted to impress her true title upon collective memory. She also states that she was "dès la mamelle ... apellée à la dignité royale, oynte et sacrée par l'aucthaurité et ministres d'icelle"19 (p. 448); and that, consequently, she will carry the title of queen until her death, whether her enemies like it or not. She declares loud and clear: "Je mourrois royne en despit d'eux" ${ }^{20}$ (p. 470). Her status as queen is both the essential component of her identity and the proof of her credibility. Mary signs the vast majority of her letters with her title, "Royne d'Escosse, douairiere de France" ${ }_{21}$ (p. 455, 464, etc.). Time and again she describes her present treatment as a captive, a condition unworthy of her rank, which is another way to call attention to her royal identity. The signature of a letter to Elizabeth goes beyond the expected formalities to reveal that Mary blames her for the unjust and unexpected treatment inflicted upon her: "Vostre affectionnée sœur et prisonnière, MARIE, REYNE" (p. 446, my emphasis) ${ }^{22}$.

8 Among the degrading images of Mary Stuart, the comparison to a criminal seems to be the most potent, perhaps because all the other depictions crystallize around that one. Clearly, it had a powerful impact on Mary Stuart herself, as it directly associated the two 
dramatic events that occurred in the final months of her life: the trial before her imprisonment at Fotheringhay and her death sentence. Mary Stuart's last thought shows how much she was tortured by this image of her criminality. Just a few hours before her death, she wrote to her brother-in-law: “Ce jourd'huy, après disner, m'a esté dénoncé ma sentence pour estre exécutée demain, comme une criminelle, à huict heures de matin" 23 (p. 493, my emphasis). Was this an obsession with imminent death or the fear of being remembered as a criminal by posterity?

A large part of Mary Stuart's correspondence reads like a defense: it is devoted to refuting the lies spread about her (such as the accusation of lèse-majesté). Judicial rhetoric functions on three levels: 1) vocabulary and imagery; 2) use of personal pronouns, and 3) refutatio. Terms referring to human law (accusations/accuser, avouer, condamner/ condamnation, jugement/juger, contredire, droit, innocente, nier, procédures, protester, réfuter, sentence) stand alongside terms referring to both human law and divine law, such as confesser, coupable, juste/justice, injuste, and temoin/témoigner/témoignage. Personal pronouns are pitted against each other as opposing parties would be in an interrogation. The je plays the role of the accused, alone before her judges, who are themselves designated by the impersonal pronoun ils/leur: "je leur ay dit" (p. 439); "ils m'ont dit ... sans nul contredit" (p. 458); "par dépit que je ne veux parler" (p. 459); "ils m'ont denoncé de la part de leur Royne” (p. 467); "ils me dirent... je respondy” (p. 468); “j’ay tousjours protesté" (p. 468); "oh, disent-ils" ${ }^{24}$ (p. 469). The high frequency of declarative verbs, and the use of direct discourse and present indicative give a sense of reality to the trial scene. This authenticity may come from the fact that these episodes (her trial and the following captivity) are still fresh in Mary's memory. The hearing behind closed doors by the commissaries designated among the peers of the kingdom and the Privy Council of Queen Elizabeth $^{25}$ took place at Fotheringhay in October 1586, and Mary was then incarcerated (behind closed doors) in Fotheringhay. The similar way in which both episodes are described, the sense of authenticity that Mary tries to achieve through the techniques examined above, the recurring mentions of the confrontational atmosphere, including the accusations against her and her protestations, seem to suggest that she lived her last months in captivity in much the same way that she lived through her trial several months earlier. Both in and out of the courtroom, Mary Stuart felt condemned before any trial had taken place. Clearly, her words proved ineffective at the trial itself, but she continued to hope that her pen would provide her a means to publicize the truth.

Her entire argumentation in the letters rests on classical techniques of refutation. Mary Stuart is accused of attempting to kill Elizabeth with the intention of usurping the throne of England or at the very least of participating in various plots against the life of her rival and the security of the kingdom: "On nous veut accuser d'avoir voulu troubler l'Estat et fait pratique contre la vie de ceste Royne, ou d'y avoir consenti" 26 (p. 439). Here, she simply denies participation in the crime of which she is accused and points out how irrational her opponents' arguments are: 'ils m'ont dit que j'avais beau faire, car je ne mourrai pas pour religion, mais pour avoir voulu faire meurtrir leur Reine; ce que je leur ay nié comme très faux" ${ }^{27}$ (p. 458). Why would she try to usurp the crown of England, since the crown already belongs to her by legitimate right and will be passed on, after her death, to her only son (unless, as Mary suggests elsewhere, she bequeaths her right to others should her son remain Protestant)? Elsewhere, she provides evidence of her innocence: she has chosen the common good, that is "to save the souls of this island" at the expense of her own interest and of her own life: "je n'ay plus desir de me troubler en 
ce monde que du service de son Esglise et gain des âmes de ceste isle à Dieu; pour tesmoignages de quoy à ma fin je ne veulx faillir de préférer le salut public au particulier interest de la chayr et du sang." ${ }^{28}$ (p. 453)

11 Finally, she discredits her adversaries in order to undermine their arguments. As evidence of their prejudice, she recalls that heretics have persecuted those of her house for as long as she can remember: "Tous ceux de nostre maison ont tous été persécutés par cette secte" ${ }^{29}$ (p. 462). Another proof of their unfairness, Mary Stuart argues, is her imprisonment for the last twenty years of her life even though she came to England to seek refuge at her cousin's side. This feeling of injustice and so many years spent in captivity had a strong impact on her self-image. Mary signs one of her letters to Elizabeth: "Vostre sœur, et cousine, prisonnière à tort" 30 (480, my emphasis). In her eyes, her death sentence "par les Estatz et assemblée hérétique de ce pays" ${ }^{31}$ (p. 449) is further evidence of her unjust treatment. Disillusioned with the justice of men, she turns her faith to divine justice. For a brief moment, the appeasing thought that "le jugement des hérétiques et ennemis de l'Église... est profitable devant Dieu aux enfans de son Église" ${ }_{32}$ (p. 462) gives her the feeling of winning a sort of posthumous victory, yet the sense of injustice does not disappear entirely. In one of her letters to Elizabeth in which she dwells on the mean acts of her judges and jailers, Mary Stuart reminds Elizabeth that she too will have to answer for her acts some day: "je vous ramentois que ung jour vous aurés à respondre de vostre charge aussy bien que ceulx qui y sont envoyez les premiers" ${ }^{33}$. (p. 479) In sum, references to family history, to current and past events that call into question her enemies' credibility, and to the day when divine justice will prevail and evildoers will be punished all contribute to her self-image as a victim of persecution by heretics.

There is a fine line between the image of the innocent victim and that of the martyr witness, which is prominent in the letters. The repetition of terms like témoin, témoignage, témoigner serves to impress upon the readers the image of the "witness" (he/she who gives testimony to God). ${ }^{34}$ The letters trace the emergence of a female subject who defines herself by her testimony, ${ }^{35}$ by the absolute truth (from God) that she holds and by a sort of prophetic power allowing her to see events to come. Time and again, Mary Stuart expresses her fears at the thought that "cette isle desvoyée" will be abandoned to heretics after her death: "la fin [=ma fin], laquelle j'estime heureuse de précéder à la persécution que je prévois menasser ceste isle" ${ }^{36}$ (179). The letters serve to make public her testimony, which her servants will transmit, should the letters not reach their intende recipients : "comme mes pauvres serviteurs, présentz à ceste mienne affliction, vous tesmoigneront"; "Aussi les ay-je tous chargez devant Dieu de vous compter tous mes déportemens et ceux des autres en ce faict." ${ }^{37}$ (p. 452 and 471, my emphasis) Those to whom the letters are addressed are also called upon to make her testimony public and to act as intermediaries by enlisting others to follow and disseminate her testimony, "Je vous prie lui [=au Pape] certifier que je meurs en cette même volonté que je vous écris [she asks Mendoza]... Croyez ce que ce porteur vous dira et ces deux pauvres filles qui ont été le plus près de moi. Ils vous conteront la vérité. Je vous prie la faire publier..." ${ }^{38}$ (p. 459-460). These examples, and the biblical image of the shepherd and his flock, point to the apostolic mission Mary Stuart felt she had been entrusted with: "J'assemblay hier mon petit troupeau pour leur répéter à tous ensemble ma protestation..." ${ }^{39}$ (p. 470)

The false rumors being spread about her could not only soil her name and image, but also invalidate her testimony and the purpose and meaning of her death. In order to 
reestablish her credibility, she had to demonstrate the legitimacy of her testimony. As proof of her integrity, Mary makes several allegations: when her accusers tried to force her to confess her crimes publically, she resisted, and, because she refused to make amends publicly, she was sentenced to death (p. 459): "m'exhortant à confesser et recognoistre... mes offences... ils n'ont su tirer de moy... on me menace si je ne demande pardon"40. (p. 467 and 458) Perhaps if she had asked for forgiveness, Elizabeth, satisfied in her pride, would have spared her. By highlighting this fact, Mary Stuart points out that she acted with full knowledge of the facts and that she actively participated in her destiny. By consenting to her fate through her own free will (“j”ay volontiers offert ma vie en leur hérétique assemblée" 41 (p. 452), she regained her freedom and could therefore proclaim herself to be a "Reine libre, catholique et obéissante à l'Église" ${ }^{42}$ (p. 462). According to Stephanie Cobb, voluntary submission ${ }^{43}$ is the distinctive mark of a martyr and the sign of his/her virility ${ }^{44}$. The idea of martyrdom was not new to Mary Stuart. While learning Latin at the French court she translated the stories of martyrs like Saint Catherine of Alexandria and Saint Anastasia from Ravisius Textor's De officina ${ }^{45}$. In the 1570 s, she even composed a sonnet devoted to sacrifice ${ }^{46}$. But at that time, martyrdom remained an abstract notion. She viewed intense piety as a more appropriate expression of her faith than the sacrificial rites of Antiquity:

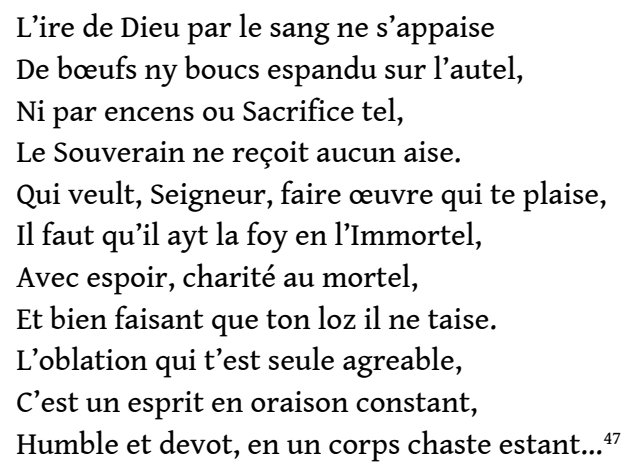

14 Mary Stuart's last letters reveal her spiritual development as well as the impact her classical education had on the way in which she perceived human destiny at death. The idea that the individual freely willed consent to his fate made him a free and responsible agent is inspired by Stoicism ${ }^{48}$, a philosophy with which Mary Stuart was very familiar ${ }^{49}$. Her claim that she is a free agent, fully in charge of her destiny ("Moy, Royne libre" 50 [p. 452]) calls into question the "illegitimate" power (in Mary's view) that Elizabeth exercized over her person and her life. Being sovereign princess and queen of Scotland, Mary refused to submit herself to the jurisdiction of the queen of England whom she did not, in any way, regard as her superior ${ }^{51}$. In her eyes, God alone had the authority of legitimizing her testimony; those who usurped this authority to pass judgment on her could only be illegitimate. To the human court that illegitimately exercized the right to punish her, Mary contrasted the divine court that is not only legitimate, but also is just and merciful ("Jésus Christ... ne manque jamais de justice", p. 476) even to those who are unworthy of forgiveness like her: "très indigne pescheresse... coupable de damnation éternelle" 52 (p. 451).

The rhetorical strategies used in these letters indicate Mary's high learning: at the court of France she studied the art of letter writing and discovered classical authors like Aristotle, Plato, and Cicero while learning Latin. It is difficult to say whether or not she studied rhetoric, but clearly she has a sense of argumentation, which was rather unusual for a woman at this time ${ }^{53}$. 
16 Another technique Mary used to make the image of the martyr-witness more real shows how familiar she was with the literary and artistic culture of her time. In her letter to Mendoza, she declares, "Ils travaillent en ma salle; je pense que c'est pour faire un échafaud pour me faire jouer le dernier acte de ma tragédie" ${ }^{54}$ (p. 459). This association between the stage that will serve as a scaffold - the last scene of her ordeal - and the dénouement of a tragedy ${ }^{55}$, the presence evoked time and again of spectators who will let others know what they saw, and the perception of herself as an actress (one who speaks words coming from elsewhere), all contribute to the impression, of a dramatization of her death sentence and of a pathetic mise en scène skillfully orchestrated. Letter - writing allowed Mary to rehearse her execution as a performance where each person plays a role.

The concept of tragedy that transpires from Mary's letters leads us to believe that she had some acquaintance with works of dramatic theory. She is aware of the emotional appeal that her extreme suffering and the cruelty of her enemies might have on her spectatorreaders. The theoreticians of this genre, which was in the midst of a revival at that time, conceived of tragedy in much the same way. In De l'art de la tragédie (1572), Jean de La Taille gives the following definition ${ }^{56}$ :

Son vray subject ne traicte que de piteuses ruines des grands Seigneurs, que des inconstances de Fortune, que bannissements, guerres, pestes, famines, captivitez, execrables cruautez des Tyrans; et bref, que larmes et miseres extremes, et non point de choses qui arrivent tous les jours naturellement et par raison commune ... : car tout cela n'esmouveroit pas aisément, et à peine m'arracheroit il une larme de l'œil, veu que la vraye et seule intention d'une tragedie est d'esmouvoir et de poindre merveilleusement les affections d'un chascun. Car il fault que le subject en soit si pitoyable et poignant de soy, qu'estant mesme en bref et nument dit, engendre en nous quelque passion.

Jean de La Taille believed that the story of David and Goliath lacked emotional appeal and therefore should not be considered for tragedy ${ }^{57}$. Mary Stuart, on the other hand, felt the tale of David was a good subject for tragedy, in particular the episode in which Saul enters the scene. The glory of David, seen as God's favor, excited passions: jealousy (Saul sees in David a formidable rival) as well as compassion and pity (Jonathan and Mikal help David escape the murderous fury of their father). In her letter to the archbishop of Glasgow, Mary Stuart identifies with this young tragic hero. In her view, with the exception of David's flight, everything in the narrative enables this identification. One striking example is the fact that both David and Mary who are wrongly suspected of lèse-majesté are called to an exceptional mission ${ }^{58}$ :

[...] au reste je voulois mourir pour obéir à l'Église, mais non meurtrir personne pour avoir leur droit; mais qu'en cela je voyois manifestement la poursuite de Saül contre David, mais que je ne pouvois fuyr, comme luy, par la fenestre; toutefois de mon sang pourroient naistre des protecteurs de ceste généralle querelle. ${ }^{59}$ (p. 459)

Mary Stuart's postmortem inventory reveals that she indeed had a particular interest in dramatic art and in the unfortunate endings unique to tragedy. A volume on the tragedies of Sophocles and the chronicles of England in which the stories of the tragic deaths of several kings are told were found among her books ${ }^{60}$. In her letter to the bishop of Glasgow, Mary Stuart mentions the political motivations behind her death sentence, and compares her tragic fate to that of Richard II, assassinated in 1399 on the order of the Duke of Lancaster "pour luy oster son droict" (p. 470).

Before we further explore the idea of "mise en scène" implicit in the concept of dramatization suggested above, we should consider the historical context. In sixteenth- 
century France, executions were public and spectacular events ${ }^{61}$. As Michel Foucault notes, they were a way to reaffirm royal power and the authority of the law in the face of criminal acts that not only threatened the immediate victim but also challenged the sovereign's power to make laws in the first place $^{62}$.

The tragic reign of Elizabeth saw the return of ancient persecutions and martyrdom was very much on people's minds. This phenomenon is particularly striking in Catholic art. According to Brad S. Gregory, what ditinguishes Catholic art of this period from that of other faiths is the visual and spectacular representation of the torments inflicted on martyrs: "Early modern Catholics differed from Protestants and Anabaptists in their emphasis on visual representations of martyrs, continuing a century-old embrace of art and architecture for religious ends." ${ }_{63}$ Émile Mâle reminds us that "les premières grandes œuvres d'art dont les Jésuites décorèrent leurs églises, furent des scènes de martyre" whose purpose was to remind the faithful of the virtue of sacrifice ${ }^{64}$. Moreover, one of the features of martyrdom is that it is a spectacle.

Le martyre apparaît comme la volonté de se donner en sacrifice visible, de s'offrir comme le centre actantiel d'un spectacle adressé à des regardants, à des narrateurs qui témoigneront à leur tour. ... le geste du sacrifice n'est ni privé ni sans spectacularité. Il doit être vu dans la mesure où il est ... un témoignage en action offert à une multitude, un instrument de conviction pour que l'événement soit vu et rapporté comme répliquant l'image sensible du sacrifice de Jésus-Christ. ${ }^{65}$

Mary Stuart declares time and again how important it is that her execution be seen as a spectacle. She fears more than anything that her execution will take place behind closed doors $^{66}$, which would deprive her of any sort of control over her self-image at the time of death. In several of her letters, she implores Elizabeth that she not be "suppliciée en quelque lieu caché, mais à la veue de [ses] domestiques et autres personnes qui puissent rendre tesmoignage de [sa] foy et de [son] obéyssance envers la vraye Église"67 (p. 445). Only a public death could demonstrate the strength of her faith, her endurance in suffering, and her courage: “[J]'espère que ma mort témoignera ma constance en la foy, et promptitude à mourir pour le maintien et restauration de l'Église catholique en cette infortunée isle" ${ }^{68}$ (p. 462). Fortitude at the time of death (the heroism that religious fervor inspires) was viewed as an expression of Grace, as a sign of "la bonne mort," which was itself the mirror of one's entire life ${ }^{69}$, as Mary Stuart well knew: “Je mourray comme j'ay $v^{2} \operatorname{scu}^{\prime 70}$ (p. 446). She viewed her death as her last chance to regain control over her life, which had been exposed to all sorts of slander ever since her condemnation to death ${ }^{71}$.

Mary was particularly sensitive to visual imagery ${ }^{72}$ and very much aware of its persuasive power. In her letters, she uses hypotyposis, which emphasizes showing over telling description, and enargeia, which gives this description its vividness. Suggestive imagery allows her to make public the execution her enemies wanted to keep secret, and to give those who will read her letters the illusion of attending the spectacle.

The word martyr appears only twice in Mary Stuart's correspondence. In her letters to the Duke of Guise, she mentions the deaths of Christ and the holy martyrs in order to validate her own death for the love of her Lord. In another letter, she quotes her jailers as proof of their determination to deprive her of her choice to die as a martyr: "Ils me dirent que j'avois beau faire, si ne seroy-je pas saincte ni martyre"73 (p. 468). Though the word martyr is rare in the letters, the image of martyrdom is quite frequent, showing once again Mary's use of imagery to appeal to her readers' imaginations and render more real to them the sacrifice to which she consented of her own free will: "recevoir le coup de mort" 
(p. 457), "suppliciée" (p. 447), "sacrifier ma vie" (p. 474), "offrir ma vie", "offrir nos corps," offrir mon sang" (p. 452, 458, 465), "respandre mon sang"74 (p. 467).

Appearing with even greater frequency in the correspondance are the word sang, the theme of blood, and the image of blood. In the last third of the sixteenth century, blood was practically a cultural obsession ${ }^{75}$. Witness the development of various genres in art and literature such as the pictorial tradition of Flanders, which, like Jesuit art, focuses on scenes of bloody massacres, the Baroque tragedy and the tragic novella, both of which privilege bloody subjects with a strong emotional appeal ${ }^{76}$, the sensational and bloody canards $^{77}$, and martyrology with the publication in the 1570 s of books like the Briefve Description des diverses Cruautez que les Catholiques endurent en Angleterre par la foy by the English Catholic writer Verstegan in exile in the Netherlands ${ }^{78}$. In the years 1587-1588, the same author published a similar work, Theatre des cruautez des heretiques de nostre temps, which achieved great success across Europe thanks to the support of Philippe II and the Society of Jesus. This work described the tragic fate of the Jesuits and their disciples in Elizabeth's kingdom and contained 29 annotated illustrations of their arrests, inquisitions, and tortures. The last illustration depicted the martyrdom of Mary Stuart.

Clearly contemporary painting and the edifying literature of the time had a strong impact on Mary Stuart's writing, but blood also had a personal resonance. In the example that follows, the association between ascendance and spilled blood emphasizes her rank and her sense of honor and duty, which she offers as proof of her dignity in defiance of those attempting to deprive her of it: "Quant à moy, je m'estime née, du costé paternel et maternel, pour offrir mon sang en icelle, et je n'ay intention de degenerer"79 (p. 464).In another letter, the parallel between the word blood (used in reference to the royal blood that flows in her veins) and the image of the executioner soaking his hands in her blood (suggestive of the sanguinary cruelty of heretics) arouses indignation: "bien que jamais bourreau n'ait mis la main en nostre sang, n'en ayez honte" 80 (p. 462). Elsewhere, the implicit evocation in the term "consanguinité" 81 (p. 478), of the family ties shared by Mary and Elizabeth- and Elizabeth's responsibility in the bloody death that awaits Mary arouses the horror of fratricide.

The word sang clearly evokes the spray of blood - and the savagery of decapitation by axe 82. At the time, punishment was "un art des sensations insupportables" ${ }^{83}$. The bloody violence of certain images in Mary's letters emphasizes the brutality of executions: "quand mes adversaires seront saoulez de mon sang innocent" ${ }^{84}$ (p. 445). The image of devouring hunger (or uncontrollable thirst) also brings to mind sixteenth-century visual representations of executions with ravenous beasts at the bottom of the scaffold waiting to be fed or avidly licking the blood flowing from the head of the victim ${ }^{85}$. The last letters of Mary Stuart were filled with images of a bloody death and terms calling to mind the noises that accompany such a spectacle. For Christians of this period, the hammers pounding as the scaffold is prepared for the execution evoke the brutality of the Crucifixion with the executioners driving nails into the hands and feet of Christ. Similar images abound in Le vray chemin of Louis de Grenade ${ }^{86}$ and in works inspired by it such as the poetry of Jean de La Ceppède ${ }^{87}$ or of Gabrielle de Coignard at the end of the sixteenth century $^{88}$. Elsewhere in the letters, the savage cries of the wolves howling after their prey ${ }^{89}$ evoke the violent atmosphere of the executions with, on the one hand, the ferocious excitement of the crowd and on the other, the solitude of the condemned: "resister seule à tant de loups hurlants apres moy"90 (p. 463). Catholics emphasized the importance of the imaginative senses in attaining union with $\operatorname{God}^{11}$. In his Exercices spirituels, Ignace de 
Loyola bases his method of praying on these senses ${ }^{92}$. Whatever the proposed scene Nativity, Passion, Harrowing of Hell- he invites the exercitants to see the characters with the eyes of their imagination, to listen with their ears to what they say, to embrace by touching the places they pass through, to fully feel and taste with the senses the infinite sweetness of divinity ${ }^{93}$.

We cannot say for sure whether or not the vivid imagery of Mary Stuart's final letters is reminiscent of specific texts she might have read. However, her correspondence from 1574 on with two Jesuits, Father Edmond Auger and Father Henri Samier ${ }^{94}$, leads us to believe that this highly suggestive imagery and the emphasis on the pathetic are not a mere coincidence.

For Mary Stuart, the image of blood spilled by beheading cannot be dissociated from the flow of blood during an offering: "l'heur que j'estime que ce m'est de repandre mon sang à la requete des ennemis de son Eglise" (p. 458 $)^{95}$. Whereas the color red evokes the crimson of the martyrs ${ }^{96}$, the contrast between red and black brings into opposition the blood of the innocent and the impurity of the sinner : "leur noir désir de mon sang innocent" ${ }^{97}$ (p. 476, my emphasis). The blood shed recalls that of Christ on the cross: "le sang de Jehsus Christ pour moy crucifié ... offrant au piedz de sa croyx volonterement mon sang pour le maintien et fidelle zelle que je porte a son Esglise"98 (p. 51-52). The cross, reminiscent of the freely consented sacrifice in Christ's image (Imitatio Christi) ${ }^{99}$, is also a reminder that men will have to account for their conduct someday and be judged accordingly. The cross that Mary Stuart brandishes when her jailers come to take away the dais that sat on top of her armchair serves as a cautionary reminder that they too will face the Last Judgment one day: “L'on m'avoit, pensant me dégrader, fait abattre mon days [...] Je leur ay montré, au lieu de mes armes audit days, la croix de mon Sauveur" 100 (p. 464). Here, the dais and the cross take on a significance quite different from that which is ordinarily attributed to them. The dais, a sign of earthly power, becomes the symbol of Mary Stuart's captivity and the humiliations she suffered at Fotheringay. The cross, a symbol of humility and of Christian submission in the hope of reward in the after life, becomes the emblem of her recovered liberty through her freely chosen martyrdom. Mary Stuart carried the cross at her execution ${ }^{101}$ for it best captured the image that she wished to leave for posterity, that of the martyr queen free in spite of her captivity.

The blood shed by Christ is redemptive: it washes away sin, purges, repairs, and regenerates. This idea of regeneration inspires the image of blood that engenders or produces growth ${ }^{102}$ ("toutefois de mon sang pourroient naitre des protecteurs de ceste generalle querelle," p. 469) ${ }^{103}$ and the prophetic vision of a new generation of witnesses coming to the world to vanquish evil and ensure the triumph of the Catholic faith. This vision provides insight into Mary Stuart's famous saying "En ma fin est mon commencement." 104

In the carceral universe of Fotheringhay, Mary Stuart had one last chance to prevent her enemies from tarnishing her memory forever. Letter-writing provided her with the means of leaving behind a testamentary image, the image of a feminine subject in full control of her being and her destiny, and endowed with the absolute truth. This highest form of knowledge provides access to other kinds of knowledge, including the prophetic knowledge reserved to the elect and allows her "to die well", as do those who have received Grace. Particularly striking is the image of a learned woman that the letters convey. It may not have been Mary's purpose to show herself in that light, but her familiarity with literature and art and her grasp of rhetoric, rather exceptional for a 
woman of that era, certainly contribute to that flattering self-portrait. Since we do not know when Mary Stuart's last letters reached her correspondents, it is difficult to say for sure whether or not they were the reason for the lasting image of the martyr queen. Nevertheless, this image seduced the imagination of Catholics and late sixteenth-century writers and has subsequently been passed on to us.

\section{NOTES}

1. The message was often conveyed by the carrier, and the sole purpose of the letter was to introduce the carrier. See Kristen B. Neuschel, Word of Honor: Intrepreting Noble Culture in SixteenthCentury France, Ithaca, Cornell University Press, 1989, p. 114.

2. "The bearer [of this letter] has promised to relate to you how rigorously I have been treated by those here, and how ill served by others." The quotations in French are from Volume VI of the Lettres, instructions et mémoires de Marie Stuart, reine d'Écosse, publ. as the originals and the manuscripts by Prince Alexandre Labanoff, 7 Vols., London, Charles Dolman, 1846. When pages are indicated, the English translations are from Letters of Mary Stuart, queen of Scotland, selected from the Recueil des lettres de Marie Stuart together with the chronological summary of events during the reign of the Queen of Scotland by Prince Alexander Labanoff, trans., with notes and an introduction, by WilliamTurnbull: http://catalog.hathitrust.org/Record/009735942, accessed 4 May 2016. All other translations are our own.

3. "They have taken everything from me here...they have nearly rendered me impotent."

4. "They came yesterday (Monday) and took down my canopy, saying that I was no more than a dead woman, and without any rank."

5. "A dead woman, and without any rank; a dead woman without the honor and dignity of a queen."

6. Le châtiment du crime au Moyen Âge $\mathrm{XII}^{e}-\mathrm{XVI}^{e}$ siècles, Rennes: Presses universitaires de Rennes, 1998, p. 122. On the loss of fama as criminal punishment, see p. 121-122.

7. As Jane Couchman notes about female correspondences of the sixteenth century, public and private were inseparable for women of this rank. See "What is 'Personal' about SixteenthCentury French Women's Personal Writings", Atlantis n' 19. 1, 1993, p. 16-20.

8. "'A Memorial', a relic of the self that can be unearthed later on." On the commemorative function of letters, see Brigitte Diaz, L'épistolaire ou la pensée nomade, Paris, PUF, 2002, p. 131.

9. "I have written with the same purpose to his Holiness."

10. Ibid., p. 149.

11. Ibid., p. 150.

12. On the ostensible letter, see Geneviève Haroche-Bouzinac, L'épistolaire, Paris, Hachette, 1995, p. 33-34.

13. I paraphrase Michel Foucault, "L'écriture de soi," Corps écrit 5, 1983, p. 17 and 23.

14. See Dictionnaire des genres et notions littéraires, preface by François Nourrissier, Encyclopcedia Universalis, Paris, Albin Michel, 2001, p. 449.

15. Neuschel notes that "the vocabulary used [by nobles in their] letters to describe their requests and promises to one another is heavily weighted with words that convey or cause action, if only in anticipation of reaction in their recipients" (117).

16. Labanoff, op. cit., vol. 1, p. 472. 
17. Hidden by Chateauneuf, the French ambassador in London, a letter containing information about what had happened at Fotheringhay arrived in Paris the $6^{\text {th }}$ or $7^{\text {th }}$ of March, 1587. However, according to James Emerson Philips, these were primarily edifying accounts like those of John Leslie, Adam Blackwood, the Scottish Jesuit William Crichton or even George Crichton, the sonin-law of Blackwood, most likely inspired by the partisan literature at the end of the sixteenth century. See J. E. Philips, "Catholic Counterpropaganda on the Execution : 1587", in Images of a Queen. Marie Stuart in Sixteenth-Century Literature, Berkeley, University of California Press, 1964, p. 143-170.

18. In spite of the numerous self-images projected back to her through her correspondents, Mary Stuart focuses almost exclusively on these three specific images. For more on the function of the recipient in the construction of self, see Diaz, op. cit., p. 161-162.

19. "from the breast...called to royal dignity, anointed and consecrated by its authority and ministers", p. 375.

20. "I will die a queen in spite of them."

21. The "Queen of Scotland, Dowager of France."

22. "Your affectionate sister and prisoner, MARY, QUEEN."

23. "Today, after dinner, I was told of my sentence to be executed tomorrow, like a criminal, at eight o'clock in the morning."

24. "I told them"; "they told me...without contradiction"; "out of spite, because I will not speak"; "they have accused me on behalf of their queen"; "they told me... I responded"; "I always protested"; "oh, they tell me".

25. On October $11^{\text {th }} 1586$, the commissaries, officers of justice, and members of the Privy Council of Queen Elizabeth arrived at Fotheringhay where Mary Stuart had been transferred and would remain until her death. Initially, she refused to appear before this committee, but after receiving the authorization to consult the list of those appointed to judge her, she agreed. The interrogation took place the $15^{\text {th }}$ and $16^{\text {th }}$ of October. On October $25^{\text {th }}$, the committee, gathered at Westminster, announced her death sentence. A few days days later, it was confirmed by the Parliament of England. All of these facts are reported in the Journal of Dr. Dominique Bourgoing, the only one among Mary Stuart's servants authorized to see her until the end.

26. "They accuse us of wanting to disturb the government and of plotting against the life of this queen, or at least of having approved such a plot".

27. "They told me that, whatever I may say or do, it will not be for the cause of religion that I shall die but for having endeavoured to murder their queen. This I denied, as being utterly false." In England, during this period, Catholics were considered rebels and sentenced to death for treason. See Brad S. Gregory, Salvation at Stake. Christian Martyrdom in Early Europe, Cambridge, Harvard University Press, 1999, p. 274.

28. "I have no more desire to trouble myself in this world with anything other than the service of his Church, and the gaining of the souls of this island to God; for evidence of which at my end I would not fail to prefer public salvation to the private interest of flesh and blood" (p. 378).

29. "Those of our house have all been persecuted by this sect."

30. "Your sister and cousin, Prisoner wrongfully."

31. "by the government and heretical parliament of this country" (p.376). On this feeling of injustice, see: "par sa grâce, j'ai eu le cœur de recevoir cette très injuste sentence des hérétiques avec contentement" (p. 458); "qu'ils passent outre leur injustice" (p. 459); "estant preste par injuste jugement d'estre mise a mort" (p. 462) ["through his grace, I have had the heart to receive with resignation this unjust sentence rendered by heretics"; "they may proceed with their injustice" (p. 187); "I am ready to be put to death because of their unjust judgment"].

32. "The judgment cast by heretics and enemies of the Church... is profitable before God to the children of his Church." 
33. "I must remind you, that one day you will have to answer for your charge, and for all those whom you doom."

34. On this notion of witness, see Tragédies et récits de martyres en France (fin XVI -début XVII siècle), Christian Biet and Marie-Madeleine Fragonard eds., Paris, Classiques Garnier, 2009, p. 56-67.

35. Speech and the profession of faith are crucial for the martyr. See Nikki Shepardson, Burning Zeal. The Rhetoric of Martyrdom and the Protestant Community in Reformation France, 1520-1570, Bethlehem, Lehigh University Press, 2007, p. 57-58: “The proper confession of the faith [...] was the defining mark of the martyr. The longer narratives in the martyrologies focused not on the death, but on the oral or written confession and/or interrogation - in other words, the statement of faith. The martyr himself often sent letters to friends, family members, or pastors containing his statement with instructions 'to give word' or to make public his confession."

36. "my end, which I am happy to think will precede the persecution that I foresee threatens this island" (p. 204).

37. "as my poor servants, present at my affliction, will testify to you" (p. 378); "Before God, I charged them with telling you about my conduct, as well as that of those around me."

38. "I beg you to assure him that I die in the determination which I have communicated to you... You may believe all that the bearer of this shall tell you, and also those two poor girls who have been with me throughout this time. They will tell you the truth. I beg you to make it known to the world."

39. "Yesterday I gathered my flock to share my protestations with them once again."

40. "forcing me to confess and recognize...my transgressions... they have not been able to draw out of me; I am threatened, if I do not beg pardon."

41. "I willingly offered my life before their heretical parliament."

42. "A free queen, loyal to the Catholic church."

43. This idea of voluntary submission is repeated time and again in the letters: "pour moy, je suis resolue de mourir pour la mienne [=sa religion]" (p. 439); "avecq une constante résolution de souffrir la mort" (p. 475); "je vous ai bien voulu dire ce dernier adieu, étant résolue de recevoir le coup de la mort, qui m’a été samedi dénoncée" (p.457); "offrant... volontèrement mon sang" (p. 452); “j’offrois volontairement de respandre mon sang en la querelle de l'Église catholique” (p. 467); “je voulois mourir pour obéir à l'Église"(p. 469) [I am resolved to die for my religion;with a constant resolve to endure death; I wanted to say farewell to you one last time. I am resolved to endure the death sentence that was announced to me on Saturday; willingly offering my blood; I willingly offered my blood for the cause of the Catholic Church; I was willing to die in obedience to the Church.]

44. On the question of virility, see Stephanie Cobb, Dying To Be Men, New York, Columbia University Press, 2008, p. 67-68: "Real men choose to die rather than acquiesce to another's will. The martyrs' complicity in their death shows that they are not victims of circumstances but fully in charge of their destinies; it also instills in the readers the confidence that they control their own future."

In his Registre-Journal, Pierre de L'Estoile underlines Mary Stuart's virility: “elle se presenta en la mort avec une resolution genereuse, et plus que masle, monstrant beaucoup de fermeté en sa religion" [she faced death with a strong resolve, more than manly, with great faith in her religion"]. See Registre-Journal du règne de Henri III, Madeleine Lazard et Gilbert Schrenck eds., t. 5, TLF n 542, Geneva, Droz, 2001, p. 268.

45. See Sylvène Edouard, "Un exercice scolaire et épistolaire: les lettres latines de Marie Stuart, 1554", Paris, Cour de France.fr, 2013. Unedited article put online January $1^{\text {st }} 2013$ (http://courde-france.fr/article2597.html). The Latin manuscript 8660, published by Anatole de Montaiglon under the title Latin Themes of Marie Stuart, Queen of Scots, London, The Warton Club, 1855, contains the themes the young Mary was asked to render in epistolary form and in Latin. 
46. Queen Mary's Book. A Collection of Poems and Essays by Mary Queen of Scots, P. Stewart-Mackenzie Arbuthnot ed., London, George Bell and Sons, 1907, p. 166-167.

47. "The wrath of God the blood will not appease/of bulls and goats upon His altars shed,/Nor clouds of fragrant incense upward spread/He joyeth not in sacrifice like these./Those, Lord, who would Thee in their offerings please,/Must come in faith, by hope immortal led,/With charity to man, and duteous tread/Thy paths, unmurmuring at Thy high decrees./This the oblation which is sweet to Thee:/A spirit tuned to prayer and thoughts divine,/Meek and devout in body chastely pure", Queen Mary's Book, A Collection of Poems and Essays by Mary Queen of Scots, p. 111.

48. On these questions of agency, free will, determinism, see Jean-Joël Duhot, La conception stoïcienne de la causalité, Paris, Vrin, 1989, p. 243. On the differences and similarities between Stoic and Christian ethics and on the evolution of their relationship over the course of the sixteenth century, see Stoïcisme et christianisme à la Renaissance, A. Tarrête, Cahiers V.-L. Saulnier ed., $\mathrm{n}^{\circ} 23$, Paris, Éditions d'Ulm, 2006.

49. Among the books belonging to Mary Stuart, John Durkan mentions a volume by Antonio Guevara on the Stoic philosopher Marcus Aurelius as well as a manuscript by John Leslie that treated different questions crucial to the Christian Stoic movement in the last third of the sixteenth century. See "The library of Mary, Queen of Scots", in Mary Stewart Queen in Three Kingdoms, ed. Michael Lynch, Oxford: Basil Blackwell, 1988, p. 82 et 91 . This inventory is held today to be the most reliable. Durkan makes numerous corrections to the inventory published in 1889 by Julian Sharman, The Library of Mary of Scots, who relied on the inventories of 1569 and 1578 , reproduced in 1815 by T. Thomson and, in 1883, by J. Robertson.

50. "I, a free Queen."

51. See p. 469-470. Also as a Scot, she was not subject to English laws. On the ambiguous situation of Mary Stuart regarding the queen of England, see Lisa Hopkins, "Renaissance Queens and Foucauldian Carcerality", Renaissance et Réforme n 20. 2, 1996, p. 20-21: "Mary, Queen of Scots... occupied an uneasy ground between two contradictory positions. ... As sovereign queen of another country [Scotland], she had to be accorded a certain respect; she was not Elizabeth's subject, which made the question of Elizabeth's rights over her person highly problematic, and it was, additionally, highly undesirable for the queen to condone regicide by having her put to death."

Another question that was repeatedly brought up in the 1570s, notably by John Leslie, bishop of Ross, is that of Mary Stuart's rights to the crown of England. See Peter Holmes, Resistance and Compromise: The Political Thought of Elizabethan Catholics, Cambridge: Cambridge University Press, 1981, p. 23-26.

52. "Jesus Christ is always just"; "unworthy, sinful, and deserving of eternal damnation".

53. According to Durkan (op. cit., p. 82), "even if Mary had not mastered the art of demonstrative reasoning, it is likely that she had had some schooling in France in the dialectic of Peter Ramus, who had enjoyed the patronage of her uncle, the cardinal of Lorraine".

54. "They are working in my room; I believe they are preparing my scaffold to have me act out the final scene of my tragedy."

55. The death of the tragic hero can effectively constitute the last event of the play, although ordinarily it is one among other events that result from the final coup de théâtre and that create the so-called catastrophe. The theatrical catastrophe is an integral part of the dénouement.

56. Jean de La Taille, De l'art de la tragédie, F. West ed., Manchester, Manchester University Press, [1572] 1939, p. 24: "Its true subject only concerns the pitiful ruin of great Lords, changes in fortune, banishments, wars, plagues, famines, imprisonment, the execrable cruelty of Tyrants; in short, tears and extreme misery, and not commonplace things that come up everyday for natural reasons... Commonplace things would not move the audience easily, would not even elicit a single tear, given that the true and sole purpose of tragedy is to move and stir everyone's emotions in 
unexpected ways. Because the subject of tragedy must be both poignant and pitiable. In short, it must arouse our passions."

57. According to Jean de La Taille, the principal purpose of tragedy is to move the audience. In his view, the story of David does not inspire compassion but rather satisfaction at the idea that David vanquished the enemy of the Christians: "Voyla pourquoy tous subjects n'estants tels seront tousjours froids et indignes du nom de Tragedie, comme celuy du sacrifice d'Abraham ... et d'un autre où Goliath, ennemy d'Israël et de nostre religion, est tué par David son hayneux, laquelle chose tant s'en faut qu'elle nous cause quelque compassion, que ce sera plustost un aise et contentement qu'elle nous baillera" [op. cit., p. 25; This is why any other subject will always be cold and unworthy of the title of Tragedy, like the story of Abraham's sacrifice... as well as the story in which Goliath, an enemy of Israel and of our religion, is killed by David. This story falls short of inspiring compassion, and instead makes us feel contentment and satisfaction].

58. David believed that God alone could strike his "oint". That's why he spared Saul's life twice. David became King of Israel, and his entire family line remained on the throne throughout the history of the Kingdom of Judah.

59. "[...] besides, I was willing to die in obedience to the Church, but not with the aim of putting someone to death in order to usurp their power. In all of this I could clearly see Saul's pursuit of David, but unlike him I could not escape through the window. However, new champions of this cause will rise from my blood."

60. Durkan, op. cit., p. 83 et 90 .

61. Gonthier, op. cit., p. 154.

62. I paraphrase Michel Foucault, Surveiller et punir, naissance de la prison, Paris, Gallimard, 1975, p. 52 sq.

63. Salvation at Stake, p. 253. See also The Jesuits and the Arts 1540-1773, John W. O'Malley and S. J. Gauvin Alexander Bailey eds., Philadelphia, St. Joseph University Press, 2005, p. 123-199.

64. L'art religieux après le Concile de Trente, Paris, A. Colin, 1932, p. 114. Émile Mâle gives as an example the frescoes painted around 1582 at the Collège des Anglais by one of the Jesuits' favorite artists, a certain Nicolas Circignani, better known by the name of Pomarancio. Gone today but preserved in engravings, these frescoes tell the story of England almost entirely in terms of the torments endured by its martyrs. Among the numerous martyrs included are Fisher and Thomas More dying on the scaffold for the English Reformation (see p. 110-111).

65. "Martyrdom appears as the will to offer oneself in a visible sacrifice as the principal agent of a show addressed to spectators, to narrators who will one day testify to what they witnessed... The gesture of sacrifice is not a private act but rather a spectacle. It must be seen, since it is a live testimony, a means of convincing the spectators so that the event may be seen and recounted as the live imitation of Christ's sacrifice." See Biet et Fragonard, op. cit., p. 82.

66. Elizabeth desired an execution behind closed doors because she did not want to assume the entire responsibility for the execution of her cousin and she feared rebellions.

67. "[...] put to death in a private place but seen by her servants and others who will bear witness to her faith and obedience to the true church."

68. "Hopefully my death will bear witness to my unwavering faith and my wish to die for maintaining and restoring the Catholic Church on this unfortunate island."

69. In essay xix of Book I, Montaigne gives a series of examples to show the importance of the final moment. Among these examples illustrating these twists of fortune is that of Mary Stuart: "La plus belle Royne, veufve du plus grand Roy de la Chrestienté, vient elle pas de mourir par main de bourreau ?" [Did the most beautiful queen, widow of the greatest King of Christianity, not die by the hand of an executioner?]. See Euvres complètes, Albert Thibaudet et Maurice Rat eds., Coll. La Pléiade, Paris: Éditions Gallimard, 1962, p. 78.

70. "I will die the way I lived." 
71. On the relationships between a good life and a good death, see De bonne vie s'ensuit bonne mort: Récits de mort, récits de vie en Europe ( $\mathrm{XV}^{e}$-XVII ${ }^{e}$ siècle), Patricia Eichel-Lojkine and Claudie MartinUlrich eds., Paris: Honoré Champion, 2006. On the deaths of illustrious men and the interpretations of these deaths, see the second part of this volume.

72. Durkan op. cit., p. 89 notes Mary's interest in illustrated books: "Light-hearted entertainment was available in illustrated books attractive to Mary's strong visual sense."

73. "They said that no matter what I did, I still would not die as a saint or martyr."

74. "endure death's sentence"; "put to death"; "sacrifice my life"; "offer my life, offer our bodies, offer my blood"; "spill my blood".

75. Henri Weber notes this obsession with blood in poems about religious wars. See "Poésie polémique et satirique de la Réforme sous les règnes de Henri II, François II et Charles IX," CAIEF 10, May, 1958, p. 116.

76. Mary Stuart owned a copy of Bandello's Histoires tragiques (see Durkan, op. cit., p. 80). On the affinities between tragic novella and tragedy, see Louise Frappier, "Histoire tragique et tragédie: anatomie du pathétique dans les nouvelles de François de Rosset", Tangence n 96, Summer 2011, p. 11-25.

77. See Maurice Lever, Canards sanglants. Naissance du faits divers, Paris: Fayard, 1993.

78. See Anthony G. Petti, "Richard Verstegan and Catholic Martyrologies of the Later Elizabethan Period," Recusant History n 5 2, 1959-1960, p. 64-90 and Frank Lestringant, "Politique du martyre au temps des guerres de religion", in Politique et littérature en France aux XVI ${ }^{e}$-XVII ${ }^{e}$ siècles, Actes du colloque international Monopoli 28 septembre- $1^{\text {er }}$ octobre 1995, Paris: Didier Érudition, 1997, p. 173-194.

79. "On both my father's and mother's sides, I consider myself destined to offer my blood for the Catholic Church, and I have no intention to go against my destiny."

80. "even though no executioner has ever dipped his hand in our blood, have no shame".

81. Earlier in this same letter to Elizabeth, Mary Stuart declares herself incapable of committing such a cruel crime: "de vous remonstrer... pour ma descharge d'aulcune malveillance ou envie de commettre cruauté ou acte d'ennemye contre ceulx à qui je suis conjoincte de sang”, p. 475, my emphasis; to show you... that I am innocent of any evil deed or cruel act against those to whom I am joined by blood.

82. Men from the nobility who had plotted against the sovereignty of the monarch were beheaded by sword. Beheading by axe, as in Mary Stuart's sentence, and, before her, that of Thomas More (see illustration 27, in Ecclesiae Anglicanae trophaea, Rome, F. Zannettus, 1584, reproduced in Salvation at Stake op.cit., p. 273, required greater skill on the part of the executioner. It was a most ignominious death but also a sensational spectacle due to the great flow of blood. On death by beheading, see Gonthier op. cit., p. 154.

83. See Foucault, Surveiller et punir, op. cit., p. 18. For different perspectives on the implications of the spectacle of executions, see Michel Bée, "Le spectacle de l'exécution dans la France d'Ancien Régime", Annales ESC n 38, 1983, p. 843-862 and Thierry Pech, "Le théâtre des supplices", Littératures classiques $\mathrm{n}^{\circ} 40,2000$, p. 309-325.

84. "when my enemies have quenched their thirst for my innocent blood".

85. Gonthier, op. cit., p. 151.

86. Le Libro de la Oración y Meditación by Louis de Grenade (1566) was translated into French in 1575. We cite here from the translation of François de Belleforest, Traitté de l'Oraison et Meditation, vray chemin... mis en nostre vulgaire par F. de Belleforest Comingeois..., Paris, Chez la vefve Guillaume de la Nouë, \& Denys de la Nouë, 1608, fol. 59a et b: "Considere encor apres cecy, comme Jesus fut cloüé en la croix, \& la douleur qu'il souffroit, lors que ces gros cloux entroient en ses mains delicates, \& par les plus sensibles parties du corps. Voy aussi qu'enduroit la Vierge, voyant de ses yeux, \& oyant de ses aureilles les durs \& cruels coups, qu'on donnoit sur les membres divins du Sauveur " [Consider also how Jesus was nailed to the cross, and the pain that he suffered when 
those large nails entered his delicate hands and the most sensitive parts of the body. Consider also the horror the Virgin endured seeing and hearing with her own eyes and ears the hard and cruel blows inflicted upon the Savior's divine limbs.]

87. The Crucifixion as depicted by Jean de La Ceppède is a scene of brutal realism aimed at assaulting the senses. At one point, La Ceppède describes the inhumane way in which the executioners spalyed Christ's body out on the Cross, and appeals to our sense of hearing by focusing on the cracking of bones as Christ's limbs are dislocated under the hammer's blows. See Les Théorèmes sur le sacré mystere de nostre redemption, Yvette Quenot ed., 2 vols, Paris: S.T.F.M., 1988-189), vol. 2, p. 490, $3^{\mathrm{e}}$ Livre, sonnet XVI, vv., p. 11-14.

88. See La Mort et Passion de nostre Seigneur sur le mont de Calvaire, vv. 173-180, in Euvres chrétiennes, Colette H. Winn ed., Geneva, Droz, 1995, p. 530-531.

89. This image may be reminiscent of the biblical imagery of late sixteenth-century Catholic propaganda where Huguenots were depicted as wild beasts. See Denis Crouzet, "Imaginaire du corps et violence aux temps des troubles de religion," in Le corps à la Renaissance. Actes du XXX Colloque de Tours in 1987, Jean Céard, Marie-Madeleine Fontaine and Jean-Claude Margolin eds., Paris, Aux Amateurs de Livres, 1990, p. 122.

90. "resist alone so many wolves howling after me".

91. On the role of imagery in Jesuit spirituality, see Pierre-Antoine Fabre, Ignace de Loyola: le lieu de l'image, Paris, Vrin, 1992.

92. See Philippe Denis, "La Réforme et l'usage spirituel des cinq sens", in Le corps à la Renaissance, op. cit., p. 188.

93. This is the fifth and final exercise of the first day of the second week. See Exercices spirituels, François Courel transl. and ed., $2^{\text {nd }}$ ed., Coll. Christus $n^{\circ} 5$, Paris, Desclée de Brouwer, 1963, p. 76-77. On the widespread popularity of this work throughout Europe from the time when it first appeared in 1548, see Henri Brémond, Histoire littéraire du sentiment religieux en France depuis la fin des guerres de religion jusqu'à nos jours, 11 vols., 1916-1936, Paris, A. Colin, p. 1967-1971, vol. 1 and Pierre Pourrat, La spiritualité chrétienne, 4 vols., Paris: J. Gabalda, p. 1927-1931 vol. 3.

94. See Durkan op. cit., p. 91 sq.

95. "how fortunate I am to shed my blood upon the request of the enemies of Christ's Church".

96. Upon stepping onto the scaffold, Mary Stuart asked for red sleeves. See Bourgoing, Journal De Dominique Bourgoing, médecin de Marie Stuart, M. R. Chantelauze ed., Paris, E. Plon \& C ${ }^{\text {ie }}, 1876$, p. 512-513.

97. "their dark desire for my pure blood".

98. "the blood of Jesus Christ, who was crucified for me...willingly offering my blood at the foot of His cross, thus showing my zealous devotion to His Church".

99. The Imitatio Christi tradition was still very much alive. On this tradition, see Philippe Denis, Le Christ étendard. L'homme-Dieu au temps des Réformes 1500-1565, Paris: Les Éditions du Cerf, 1987, p. 39-45.

100. "They took down my dais, thinking this would humiliate me [...] Instead of the coat of arms on my dais, I showed them the Cross of my Savior."

101. Dr. Bourgoing makes mention of it in his Journal. See p. 578.

102. This idea most likely comes from Tertullian's Apologeticus $n^{\circ} 50$, s. 13 : semen est sanguis christianorum [the blood of Christians is seed].

103. "However, new champions of this cause will rise from my blood."

104. "In my end is my beginning." 


\section{ABSTRACTS}

Between the announcement of her death sentence on November 19th, 1586, and her execution on February $8^{\text {th }}, 1587$, Mary Stuart wrote ten letters, most likely unbeknownst to her guards in the Fotheringhay castle. What may have motivated Mary Stuart to devote the last hours of her life to writing letters? This paper argues that letter-writing, in which we recognize her Humanist knowledge and skills, provided her the means of constructing a favorable image of herself, thus preventing her enemies from tarnishing her memory forever. Since we don't know if these letters reached Mary's correspondents, we cannot say for sure whether or not they were the reason for the survival of the image of the martyr queen. Nevertheless, it is this image that seduced the imagination of Catholics and late sixteenth-century writers and that, through them, was passed on to us.

Entre l'annonce de sa condamnation à mort le 19 novembre 1586 et son exécution le 8 février 1587, Mary Stuart a rédigé une dizaine de lettres à l'insu de ses gardes dans la prison de Fotheringhay. Pour quelles raisons a-t-elle consacré les dernières heures de sa vie à la rédaction de ces lettres? Cette étude suggère que l'écriture épistolaire, dans laquelle nous reconnaissons ses savoirs humanistes, lui a fourni le moyen de brosser un portrait favorable d'elle-même et d'empêcher de la sorte ses ennemis de souiller sa mémoire. Comme nous ne savons pas si ces lettres sont parvenues aux personnes à qui elles étaient adressées, il est difficile de dire au juste l'impact qu'elles ont pu avoir sur l'image de la reine martyre qui est restée de Marie Stuart. C'est en effet cette image qui a séduit l'imagination des Catholiques et des écrivains de la fin du seizième siècle et qui, par leur intermédiaire, est parvenue jusqu'à nous.

\section{INDEX}

Mots-clés: Stuart (Marie), lettres, identité (construction de), martyre, mort, Christ, sacrifice Keywords: Stuart (Mary), letters, martyr, identity (construction of), Christ, death, sacrifice

\section{AUTHORS}

\section{COLETTE H. WINN}

Washington University in Saint Louis 